\title{
Counseling on the Importance of Electrical Installation Safety in Tegalpanjang Village
}

\section{ILMAN HIMAWAN KUSUMAH, MUHAMAD SHOBIRIN, EKA MUHAMMAD HARYADI, ADI MULYADI, RANTI NURDIANSARI}

\author{
Universitas Nusa Putra \\ Email: ilman.himawan@nusaputra.ac.id
}

Received 17 August 2021 | Revised 16 November 2021 | Accepted 17 November 2021

\begin{abstract}
Electricity has a very vital role in everyday life, therefore the electricity network must be properly maintained and protected, otherwise, not only disrupt the need for electricity but it can also endanger human safety. One type of electrical hazard that often arises is fire that caused by the electrical equipment used was not under the PUIL Standard (General Requirements for Electrical Installation in Indonesia) and COE (Certificate of Operation Eligibility). Beside carelessly installation that not comply with regulations that often cause electrical short circuit.. The purpose of this community service is to provide knowledge about the safe and correct household electrical installations to residence of Tegalpanjang especially school student so they can also provide information to other community members about dangers and utilization of electricity as well as correct electrical installation. The result of this service activity is the participants has knowledge upgrading and understanding about the dangers and use of electrical installations to avoid fires caused by electrical short circuits.
\end{abstract}

Keywords: Electrical, PUIL, SLO, Tegalpanjang Village

\section{INTRODUCTION}

Electricity has a very vital role in daily life, therefore the electricity network must be maintained and protected properly and properly. (Amiruddin, 2008). Otherwise, not only the need for electricity will be disrupted but it can also endanger human safety. One form of electrical hazard that often arises is fire. (Ketenagalistrikan, 2016) One of the causes of the fire is because the electrical equipment used is not following PUIL Standards (General Requirements for Electrical Installation in Indonesia) and SLO or COE (Certificate of Operation Eligibility), low quality of electrical equipment and cables used, and installation that are original and not following regulations.

One way to avoid the dangers of electricity is with a good and safe installation of home electricity. In general, people who can install electrical installations in the village are very limited. These capabilities are usually obtained from looking at examples of existing installations or having been involved in the installation process before. Then, the experience is tried to be applied when working together to help build people's homes. The process of electrical installation can be said to be quite simple so that people without a special educational background can do it. 
Based on the situation, it is necessary to conduct a socialist to the villagers of Tegalpanjang especially the school students in the form of counseling and training of household electrical installations. This service is expected to provide knowledge to the community about the dangers and utilization and installation of household electricity that is safe and correct. (Fathkhurrozi, 2017)

\section{METHOD}

\subsection{Method of Activity}

The methods used in this activity are as follows (Solihin, 2021 ):

1. Lecture method, which is used to describe the information that has been compiled by the presenter. This method, conveyed knowledge about electricity and its dangers as well as general regulations of residential electrical installations, as well as Safety, Health and Safety (K3) in the field of household electrical installations in the community. Figure 1 shows the way of delivering material to the participants.

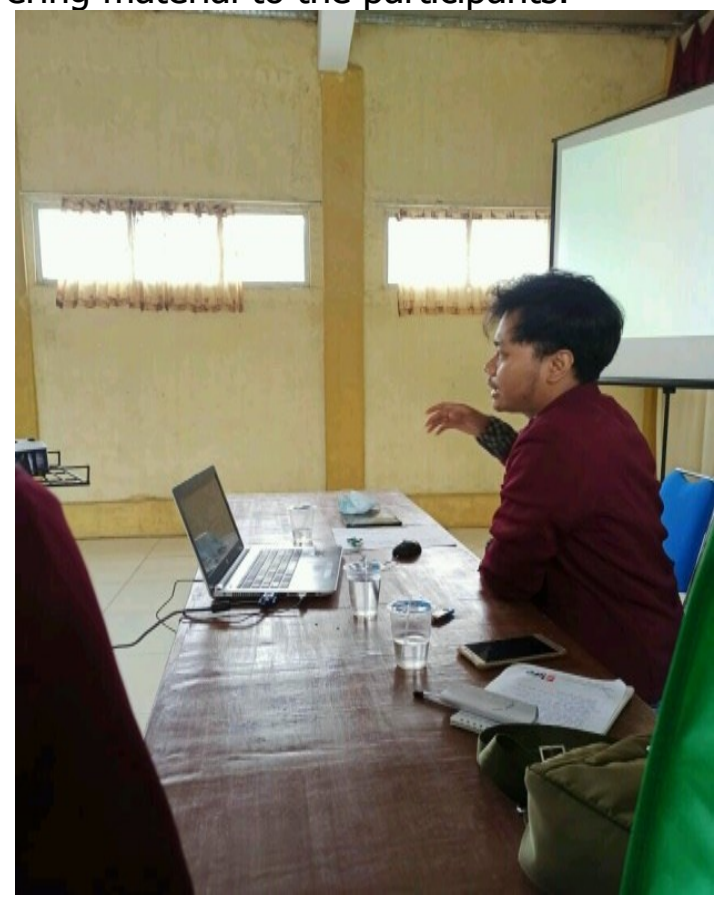

Figure 1. Delivering material

2. Q\&A method, which is used to respond to the extent of the listener's understanding of the information that has been conveyed by the presenter. To increase the enthusiasm of the participants, participants who do question and answer with the presenter will be given a prize. It is showed in Figure 2.

3. Simulation method, this simulation is shown through video that is used to show demonstrations and simulations of the working steps of each material given so the participant can imagine how to do the step explained by presenters. (Sultan, 2021).

4. Evaluate each participant in the correct understanding and installation skills of electrical. (Suryatmo, 1996) 


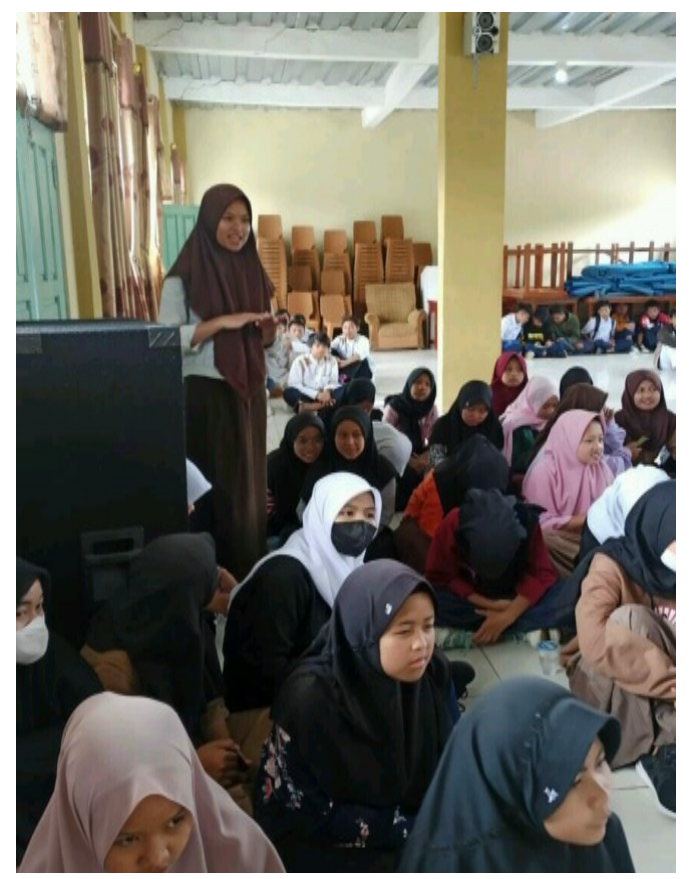

Figure 2. Question and Answer with Participants

\subsection{Schedule of Activities}

Counseling activities on the importance of electrical installations following PUIL (General Requirements for Electrical Installation in Indonesia) and COE (Certificate of Operation Eligibility) as well as an explanation of the dangers of short-circuit causes of video-based house fires in Tegalpanjang Village are conducted on:
Day
: Sabtu
Date $\quad: 27$ Maret 2021
Time : $08.00-$ Finish
Location : Ma'had Ummul Quro Al-Islami Foundation Hall Tegalpanjang village

\section{RESULTS AND DISCUSSION}

\subsection{Preparation of activities}

Before the activity is carried out, the following preparations are made:

1. Conducting library studies on the implementation of design/planning, installation, and inspection of installations are good and correct.

2. Preparing tools and materials that will be used during counselling.

3. Determining the implementation time and length of counselling activities Determine and prepare the material to be delivered in the counselling.

\subsection{Implementation of activities}

Counseling activities to the community were conducted in the hall of Yayasan Ma'had Ummul Quro Al-Islami located in Tegalpanjang Village, Cireunghas District, Sukabumi Regency on March 27, 2021. 


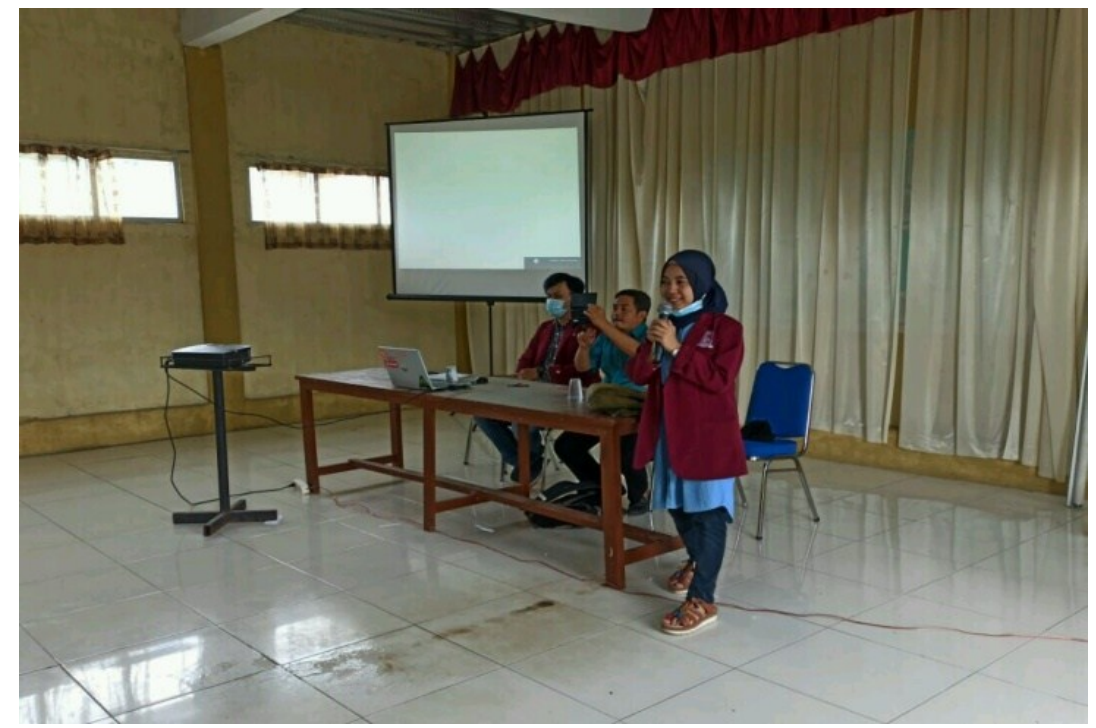

Figure 3. Opening Ceremony by Organizing Committee

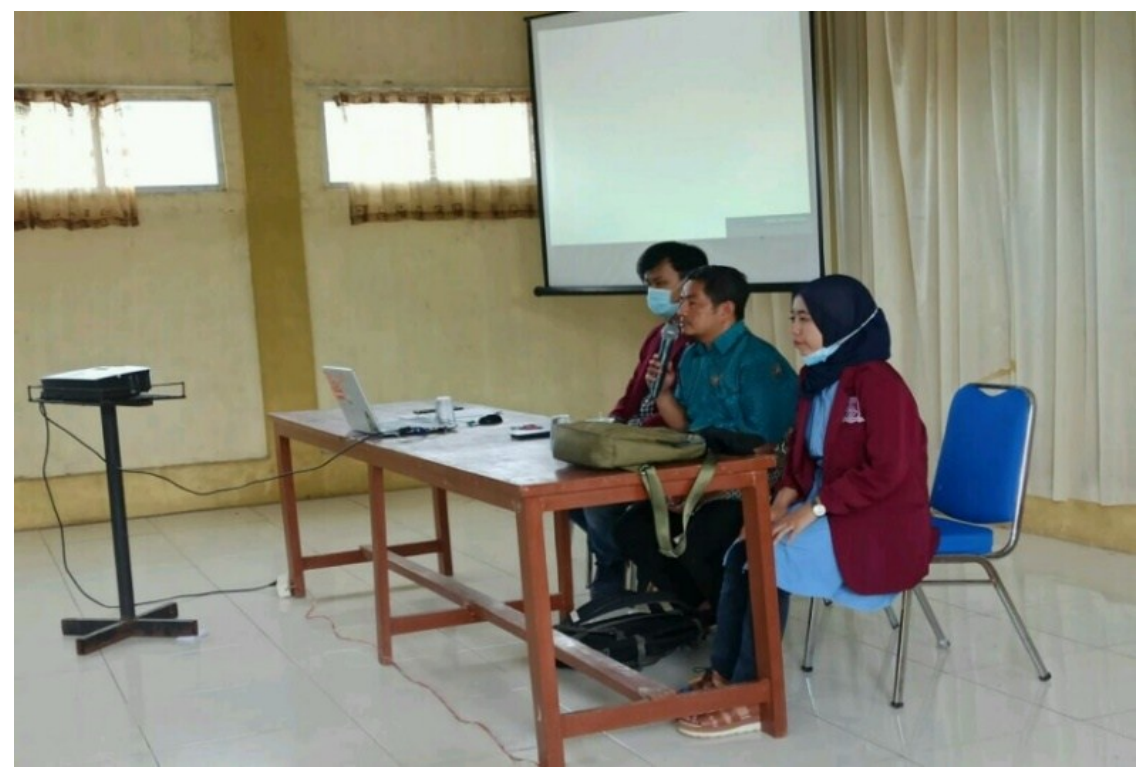

Figure 4. Speech by Ummul Quro foundation

This counseling was attended by 123 participants consisting of students who studied at the Foundation Ma'had Ummul Quro Al-Islami. Figure 3 and 4 shows the activity that began with opening by the organizing committee and also a speech from the school and then continued with the delivery of materials by presenter and also with a question and answer with the participants. Figure 5 shows the situation of conducting counseling to students about the appropriate household electrical installations based on the standard. 


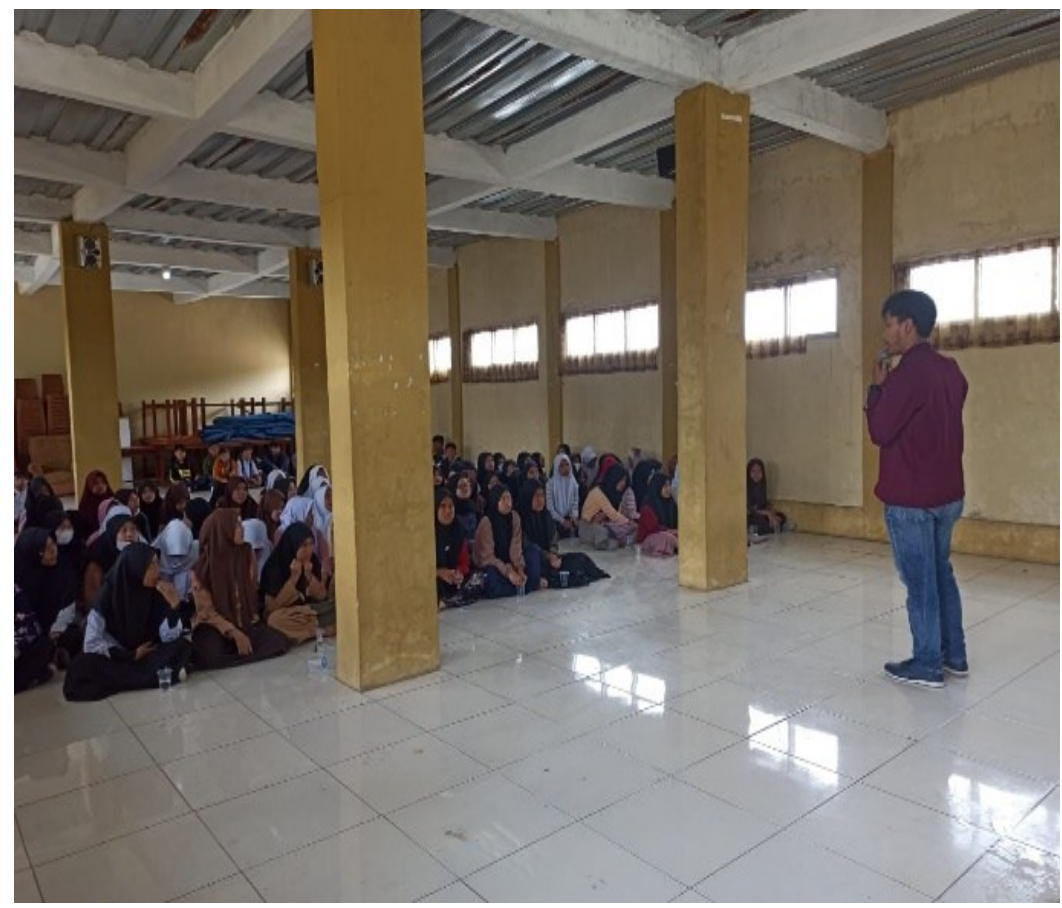

Figure 5. Material Delivery

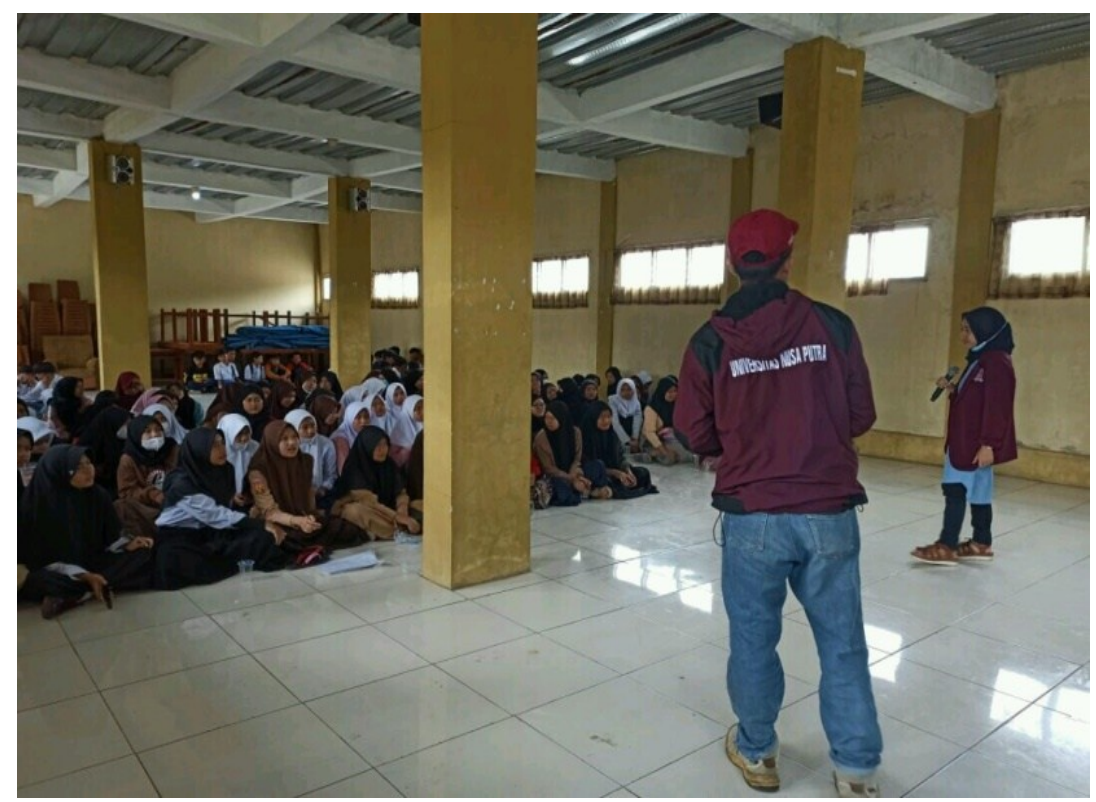

Figure 6. Ice-Breaking with Participants

When the first explanation of the materials, the participants do not understand how to install the correct installation and do not yet understand the dangers that will be faced in the installation of electrical equipment, especially the danger of electrical short circuit. Figure 6 shows Ice-Breaking process with participants because this is the first time counseling about electrical installations based on the video. After the explanation, awareness of participants about PUIL Standards (General Requirements for Electrical Installation in Indonesia) and COE (Certificate of Operation Eligibility) is increasing. 


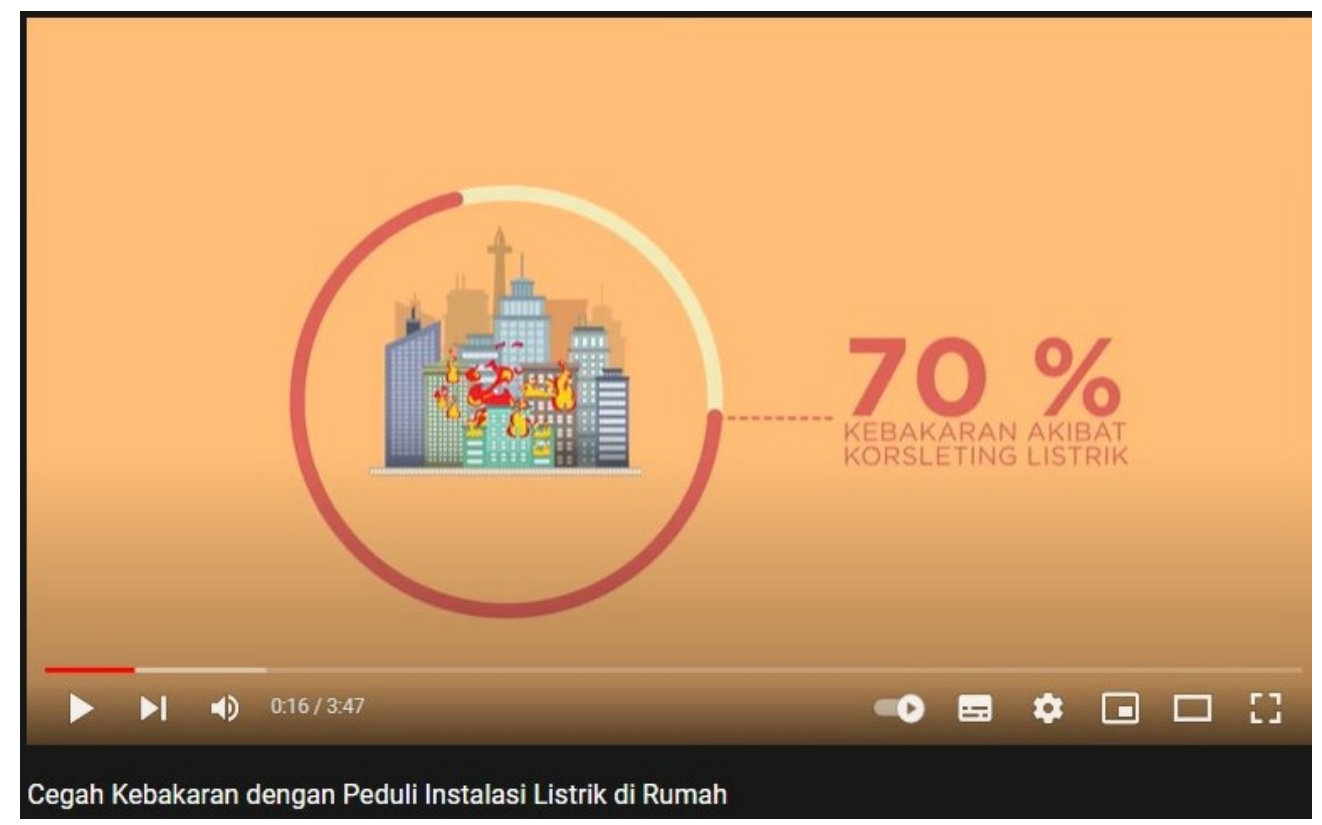

Figure 7. Material of the Counseling

(PLN, Cegah Kebakaran dengan Peduli Instalasi Listrik di Rumah., 2015)

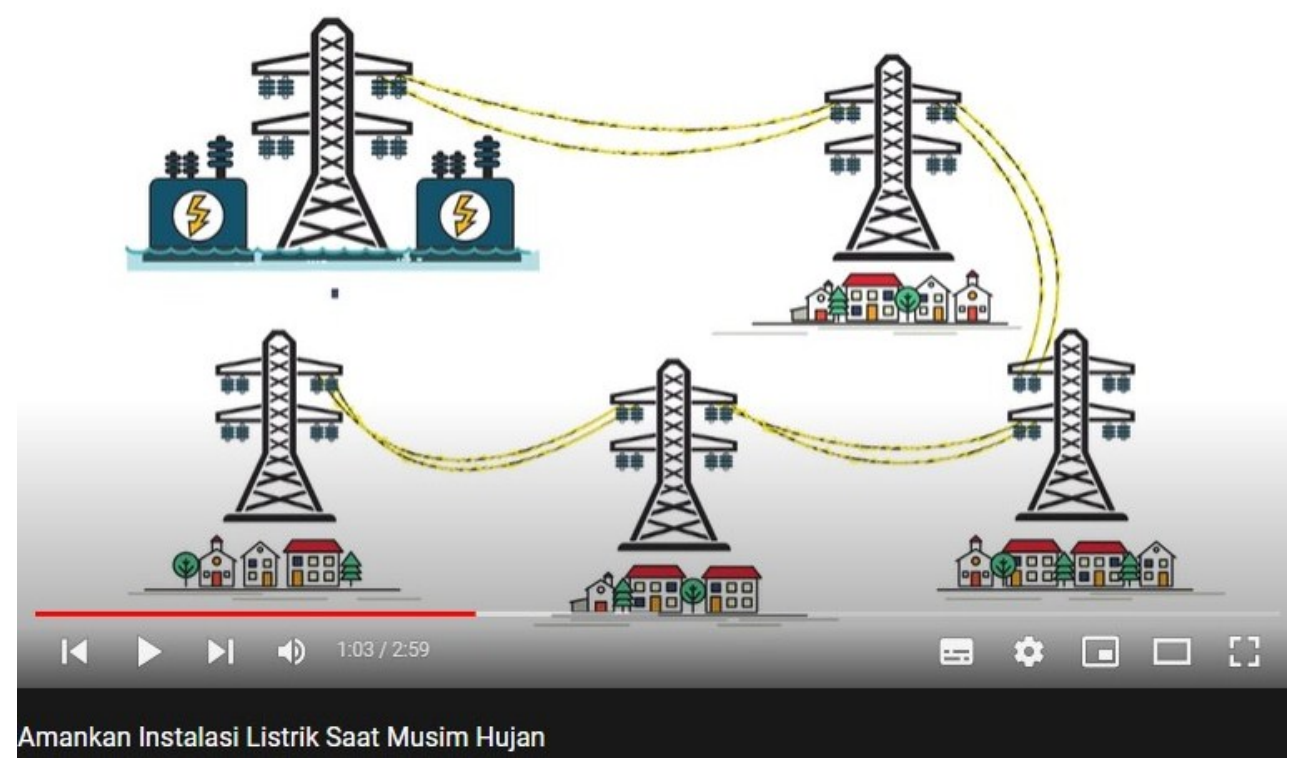

Figure 8. Material of the Counseling

(PLN, Amankan Instalasi Listrik Saat Musim Hujan, 2016).

Figure 7 and 8 shows material of the counseling that delivering by video playing accompanied by presenter explanation. 


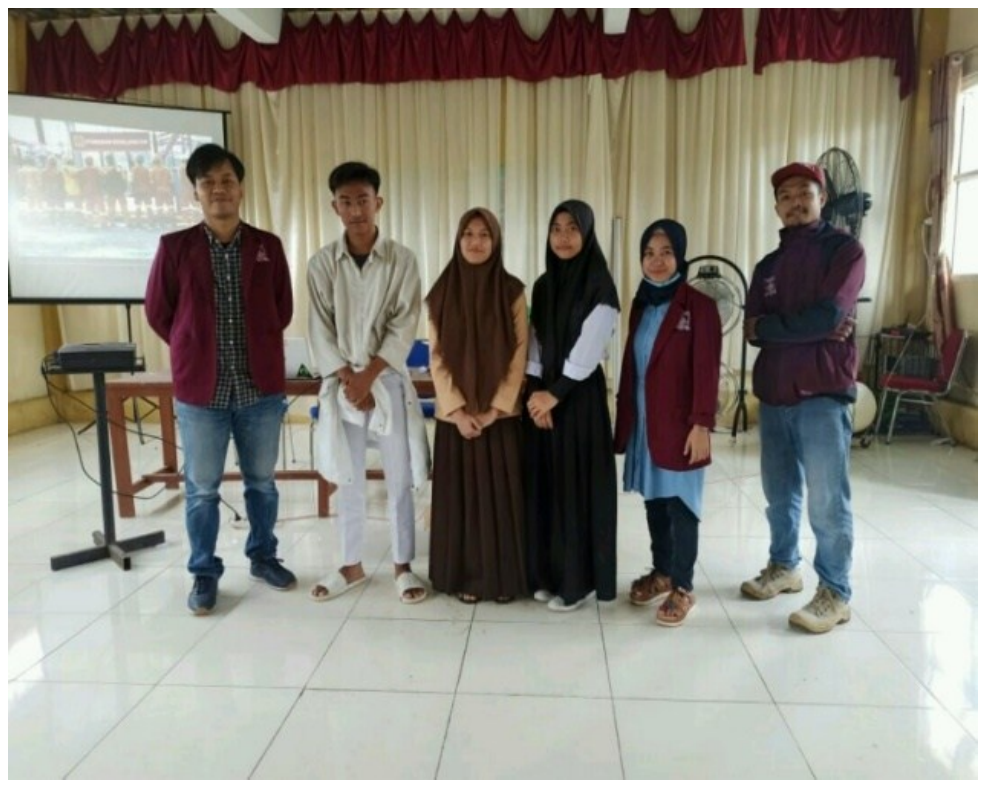

Figure 9. Conveying the Impression of the Participant

With this counseling, the participants can understand how to install electrical equipment properly and can also provide information to people closest to them or residents to see how the installation is correct and provide information on how dangerous it is if the installation of electrical installations is not done correctly. Based on the impressions and messages from the participants' representatives as shown in figure 9 participants stated that they are very happy and enthusiastic about this counseling activity because this is the first time counseling about electrical installations based on the video in their place. Also they said that the counseling has increased knowledge of the benefits of electricity, electrical hazards and awareness of participants in maintaining electrical installations.

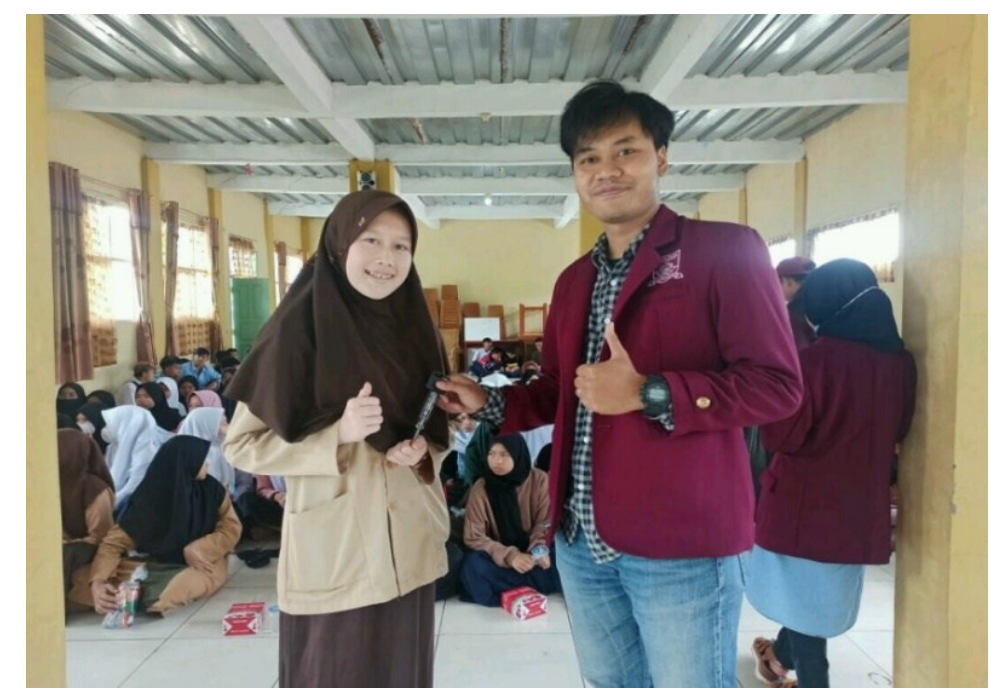

Figure 10. Gives Appreciation to the Most Active Participants

Finally, in the end of counseling session the organizing committee gives appreciation to the most active participants by gives a present as shown in Figure 10. 


\section{CONCLUSION}

Community service activities conducted by students of group 9 Nusa Putra University on 27 March 2021, on "Counseling the Importance of Electrical Installation Following PUIL Standards (General Requirements of Electrical Installation and COE (Certificate of Operation Eligibility)" has been implemented well. The benefits of the activity are as follows:

a. Increased awareness of participants about PUIL Standards (General Requirements for Electrical Installation and COE (Certificate of Operation Eligibility)

b. Increased participants's knowledge of the benefits of electricity

c. Increased knowledge of electrical hazards

d. Increased awareness of participants in maintaining and maintaining electrical installations

The advice from the author should be carried out again in Tegalpanjang village with increased knowledge of electrical installations and conducting training on the installation of electrical installations following the standards applicable to improve the expertise of the community in the form of correct electrical installation training, namely following PUIL 2011 (SNI 0225-2011) (Sultan, 2021).

\section{ACKNOWLEDGEMENT}

The author thanked the people of Tegalpanjang Village as well as to the Ma'had Ummul Quro Al-Islami Foundation who received us well and all fellow students and students of the group 9 Nusa Putra University in 2021 who have given energy, mind, and financial support to this devotion.

\section{LIST OF REFERENCE}

Amiruddin, A. (2008). Pengetahuan dasar Listrik. Jakarta: Erlangga. Bishop, Owen. Dasar Dasar Elektronika.

Fathkhurrozi, B. e. (2017). Penyuluhan dan Pelatihan Instalasi Listrik Rumah Tangga Bagi Masyarakat Desa Madusari Kec. Secang Kab. Magelang. J. Pengabdi. Masy, vol. 1, no. 1, pp. 13-20.

Ketenagalistrikan, D. J. (2016). Keselamatan dan Pemasangan Instalasi Listrik Voltage Rendah untuk Rumah Tangga. Jakarta: Direktorat Jendral Ketenagalistrikan.

Nasional, B. S. (2011). Persyaratan Umum Instalasi Listrik 2011 (PUIL). Jakarta: Panitia Teknis Instalasi dan Keandalan Ketenagalistrikan, "SNI 0225:2011.

PLN. (2015). Cegah Kebakaran dengan Peduli Instalasi Listrik di Rumah. Retrieved from https://www.youtube.com/watch?v=hf6zoUOQq2w

PLN. (2016, Maret 20 ). Amankan Instalasi Listrik Saat Musim Hujan. Retrieved from youtube:

https://www.youtube.com/watch?v=gTW_OV_BsQw\&list=PLrWpVAgJjrg2YInviHI133| burxsy6BtV\&index $=2$ 
Solihin, A. A. (2021 ). Sosialisasi Pemanfaatan Era Industry 4.0 di setiap Dusun Desa Cibaregbeg Kecamatan Sagaranten Kabupaten Sukabumi, . Jurnal Abdi Putra.

Sultan, e. a. (2021). Sosialisasi Pengamanan Instalasi Listrik Berdasarkan PUIL 2011 (SNI 0255:2011) di Desa Perina Kec. Jonggat Kab. Lombok Tengah. Jurnal Bakti Nusa, Vol 2.

Suryatmo. (1996). Dasar - Dasar Teknik Listrik Edisi Kedua. Jakarta: PT Rineka. Cipta. Irasari, Pudji 2006. 